Bull. Chem. Soc. Ethiop. 2018, 32(1), 65-75.

ISSN 1011-3924

(C) 2018 Chemical Society of Ethiopia and The Authors

Printed in Ethiopia

DOI: https://dx.doi.org/10.4314/bcse.v32i1.6

\title{
HEALTH RISK ASSESSMENT OF HEAVY METALS VIA CONSUMPTION OF SPINACH VEGETABLE GROWN IN ELALLA RIVER
}

\author{
Ftsum Gebreyohannes $^{1}$ and Abraha Gebrekidan ${ }^{2 *}$ \\ ${ }^{1}$ Department of Chemistry, School of Natural and Computational Sciences, Medawalabu \\ University, Robe, Ethiopia \\ ${ }^{2}$ Department of Chemistry, College of Natural and Computational Sciences, Mekelle University, \\ Mekelle, Ethiopia
}

(Received March 1, 2017; Revised January 25, 2018; Accepted March 4, 2018)

\begin{abstract}
Water pollution with heavy metals due to discharge of untreated domestic wastes and surface runoff to the rivers is a major threat for human health that consumes vegetables grown with the polluted river. The present study aimed to examine the contamination of heavy metals through the health risk assessment via the consumption of spinach vegetable grown by the irrigation of Elalla River. Water from Elalla River, soil and spinach were analyzed for $\mathrm{Fe}, \mathrm{Zn}, \mathrm{Cu}, \mathrm{Pb}, \mathrm{Cr}$ and $\mathrm{Cd}$ using FAAS. Based on the elements analyzed, TF, DIM and HRI were calculated. The elements $\mathrm{Cr}(0.18-0.60)$ and $\mathrm{Cd}(0.021-0.023)$ in water samples $(\mathrm{mg} / \mathrm{L}), \mathrm{Zn}(316.10-$ 517.86) and $\mathrm{Cd}(16.00-16.80)$ in soil samples $(\mathrm{mg} / \mathrm{kg})$; and $\mathrm{Fe}(483.38-612.24), \mathrm{Zn}(109.86-219.72), \mathrm{Pb}(2.56-$ $3.97), \mathrm{Cr}(8.42-13.45)$ and $\mathrm{Cd}(1.62-1.91)$ in spinach $(\mathrm{mg} / \mathrm{kg})$ were exceeded the permissible limits set by FAO and Ewers and Weigert. The TF calculated were lower for all metals except for $\mathrm{Pb}$ (2.832). Although the HRI values of all studied heavy metals were found to be $<1$, the values for $\mathrm{Cd}$ and $\mathrm{Pb}$ were higher indicating alarming condition for the long term use of spinach in the studied area. Therefore, regular monitoring of heavy metals is essential to prevent excessive build up in the food chain and prevent serious health risk of population.
\end{abstract}

KEY WORDS: Vegetables, Metal accumulation, Daily intake of metals, Health risk index, Human health

\section{INTRODUCTION}

Heavy metals are inorganic elements essential for plant growth in traces or very small quantities. The presence of heavy metals in surface water is caused by weathering of soils, rocks and by anthropogenic activities that disturb the natural distribution of heavy metals in surface water [1]. Soils may become contaminated by the accumulation of heavy metals through emissions from the rapidly expanding industrial areas, mine tailings, disposal of high metal wastes, leaded gasoline and paints, land application of fertilizers, animal manures, sewage sludge, pesticides, wastewater irrigation, coal combustion residues, spillage of petrochemicals, and atmospheric deposition $[2,3]$. Long term use of sewage effluent for irrigation contaminates the soil and vegetables to such extent that it becomes toxic to plants and causes the deterioration of the soil that contains considerable amount of potentially harmful substances of heavy metals like $\mathrm{Cr}, \mathrm{Fe}, \mathrm{Cu}, \mathrm{Pb}, \mathrm{Zn}$ and $\mathrm{Cd}[3]$.

Vegetables are source of essential nutrients, antioxidants and metabolites in food item. However, their consumption by humans and animals can pose serious health hazards, because they are potential carcinogens or cause human organ dysfunction. Although, some heavy metals such as $\mathrm{Cu}, \mathrm{Zn}$ and $\mathrm{Fe}$ are essential in plant nutrition, many of them do not play significant role in the plant physiology. For instance, $\mathrm{Pb}$ and $\mathrm{Cd}$ are among the most abundant heavy metals and are particularly toxic. The uptake of these heavy metals by plants especially leafy vegetables is the path of their entry into human food chain which ends with harmful effects on health $[4,5]$. The daily accumulation of heavy metals in the environment has magnified in recent years because of population growth, industrialization and technological developments. This

*Corresponding author. E-mail: abrishgk@yahoo.com; abrishgk@gmail.com

This work is licensed under the Creative Commons Attribution 4.0 International License 
phenomenon is of great concern because heavy metals constitute considerable hazards to human health due to their toxicity, accumulative tendencies and persistence in the environment with possibilities for environmental transformation into more toxic compounds [6]. At Elalla River different municipal wastes are being disposed, cars are being washed, mostly children are using on it for showering and drink from the river and many people are consuming the vegetables grown around that River. However, there were no other studies done on this study area. Therefore, the study aims to generate baseline information on the level of heavy metal concentration in water, soil and vegetable, and undergo assessment on the suitability of Elalla River water for irrigation and other activities.

\section{EXPERIMENTAL}

\section{Description of the study area}

The Elalla River is found in Northern side of Mekelle city, Tigray, Ethiopia at a latitude of $13^{\circ} 29^{\prime} \mathrm{N} 39^{\circ} 28^{\prime} \mathrm{E}$ and longitude of $13^{\circ} 29^{\prime} \mathrm{N} 39^{\circ} 28^{\prime} \mathrm{E}$, with an elevation of 2084 meters above sea level. The climate of the region is generally sub-tropical with an extended dry period of nine to ten months and a maximum effective rainy season of 50-60 days. Considering the rainfall, atmospheric temperature and evapo-transpiration, more than $90 \%$ of the city is categorized as semi-arid with temperature of 11.5 to $30.65{ }^{\circ} \mathrm{C}$ and annual rainfall of 24.0 to $486.0 \mathrm{~mm} / \mathrm{month}$ [7]. Four sampling stations were chosen along the Elalla River over a total distance of $13 \mathrm{~km}$ based on their different pollution sources using global positioning systems reading, which are: Feleg-Daero, upstream of the river (S1) used as a control, bridge of Mekelle-Adigrat road (S2) place where water used for car wash, industry zone (S3) place where with different metal works and Mariyam Liham, place where the river leaves the city (S4).

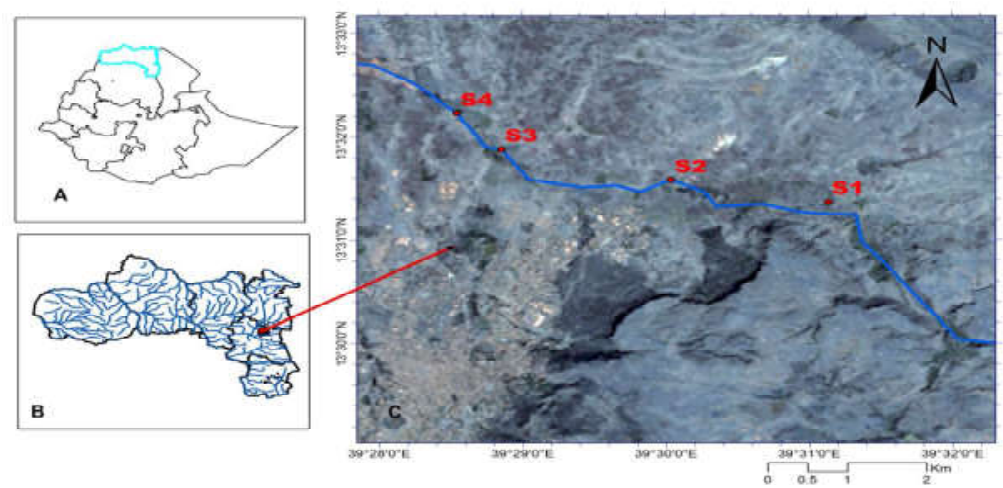

Figure 1. Map of study area: A, Map of Ethiopia; B, Map of Tigray and C, Map of study sites (S1, S2, S3 and S4).

\section{Instrument and chemicals}

A drying oven with forced air and timer (FED 53, USA) was used for drying samples and A11 Basic Analytical MILL (IKA-Werke GmbH \& Co.KG, 79219 Staufen, Germany) for grinding vegetables, analytical balance (LARK LA114, UK) and fume hood (Uethe-Hangsen D31311A, Germany) were used to exhaust chemical fumes. The Varian AA240 FS Fast Sequential Atomic Absorption Photometer (Varian, Australia) was used for the determination of metals $(\mathrm{Cd}, \mathrm{Cu}$, $\mathrm{Cr}, \mathrm{Fe}, \mathrm{Pb}$ and $\mathrm{Zn})$. 
The chemicals used were: $70 \% \mathrm{HNO}_{3}$ (BDH, England), $37 \% \mathrm{HCl}$ (Riedel-de Häen, Germany), 98\% $\mathrm{H}_{2} \mathrm{SO}_{4}$ (RSCL Ltd. Com., India) and 30\% $\mathrm{H}_{2} \mathrm{O}_{2}$ (SDSL, Mumbai, India) were used during the analysis. The reagents used for the analysis was analytical grades and double distilled water was used for digestion of the samples.

\section{Sample collection}

The water samples were collected from the four different sampling sites for three consecutive months (March-May, 2014) with $250 \mathrm{~mL}$ plastic bottles using standard sampling techniques. Before sample collection, the plastic bottles were cleaned by detergent and distilled water and then rinsed using $10 \% \mathrm{HNO}_{3}$ appropriately. During sampling, sample bottles were rinsed with sampled water three times and preserved with the addition $1 \mathrm{~mL}$ of $70 \% \mathrm{HNO}_{3}$. The samples were labeled and transported to the laboratory in icebox and stored in a refrigerator at about $4{ }^{\circ} \mathrm{C}$ prior to analysis [8].

About $1 \mathrm{~kg}$ of composite soil samples were also collected from each four sampling sites of vegetable garden using plastic spade vertically from $0-15 \mathrm{~cm}$ borehole once at each sampling day after the removal of top soil. The collected samples were thoroughly mixed, dried to constant weight in an oven, grounded and sieved with 200 mesh $(75 \mu \mathrm{m})$ sieve. The dried samples were kept in tightly closed clean sample bottles till analysis [9].

The spinach (Amaranthus caudatus) vegetable samples were collected from the selected sites, washed with distilled water to remove dust particles and air dried. The dried spinach vegetable samples were crushed using mortar and pestle. Finally, the powder was stored in tightly closed clean sample bottles until analysis.

\section{Analytical procedures}

Digestion procedures for selected heavy metals

About $50 \mathrm{~mL}$ water sample was transferred in to three digestive tubes and $10 \mathrm{~mL}$ of conc. $\mathrm{HNO}_{3}$ to the tubes containing water sample which allowed evaporating at temperature of $80{ }^{\circ} \mathrm{C}$ in a fume hood tile to half of its original volume on the digestive stove. The mixture was cooled and then filtered in to $100 \mathrm{~mL}$ volumetric flask using Whatman number 41 filter paper and the flask was diluted to the mark by using distilled water. Reagent blank also prepared to check the contamination [10]. The preconcentration was done in triplicate.

A $0.5 \mathrm{~g}$ of air-dried ground soil were transferred to the digestive tube followed by $5 \mathrm{~mL}$ of conc. $\mathrm{H}_{2} \mathrm{SO}_{4}, 25 \mathrm{~mL}$ of conc. $\mathrm{HNO}_{3}$ and $5 \mathrm{~mL}$ of conc. $\mathrm{HCl}$. The mixture was heated at $200{ }^{\circ} \mathrm{C}$ for one hour in a fuming hood and then cooled to room temperature and then $20 \mathrm{~mL}$ distilled water added and filtered. Finally, the mixture were transferred to a $50 \mathrm{~mL}$ volumetric flask, diluted to the mark and let to settle for around 15 hours [9]. The digestion was done in triplicate.

A $0.5 \mathrm{~g}$ of the powdered spinach sample was placed in to the digestive tube followed by 5 $\mathrm{mL}$ of conc. $\mathrm{HNO}_{3}$ and $3 \mathrm{~mL}$ of conc. $\mathrm{H}_{2} \mathrm{O}_{2}$. The mixture was heated at $160{ }^{\circ} \mathrm{C}$ for $1 \mathrm{~h}$ in a fuming hood and then cooled to room temperature. After the addition of $20 \mathrm{~mL}$ of distilled water, the mixtures were filtered, transferred to a $50 \mathrm{~mL}$ volumetric flask, diluted to the mark and let to settle for 15 hours. The digestion was done in triplicate.

\section{Heavy metals analysis}

The heavy metals $\mathrm{Fe}, \mathrm{Zn}, \mathrm{Cu}, \mathrm{Pb}, \mathrm{Cr}$ and $\mathrm{Cd}$ in soil, water and vegetable samples were determined by flame atomic absorption spectrophotometer (FAAS) that uses air/acetylene as oxidant. The instrument working condition and detection limits were shown in Table 1. 
Table 1. Instrument working condition and method detection limit (MDL) for heavy metal analysis in water, soil, and vegetable samples.

\begin{tabular}{|l|c|c|c|c|c|c|}
\hline \multirow{2}{*}{ Parameters } & \multicolumn{6}{|c|}{ Element } \\
\cline { 2 - 7 } & $\mathrm{Cd}$ & $\mathrm{Cr}$ & $\mathrm{Cu}$ & $\mathrm{Fe}$ & $\mathrm{Pb}$ & $\mathrm{Zn}$ \\
\hline Wavelength $(\mathrm{nm})$ & 228.8 & 357.9 & 324.7 & 248.3 & 217.0 & 213.9 \\
\hline MDL for water $(\mathrm{mg} / \mathrm{L})$ & 0.01 & 0.02 & 0.01 & 0.02 & 0.01 & 0.05 \\
\hline MDL for soil $(\mathrm{mg} / \mathrm{kg})$ & 1.0 & 1.0 & 1.0 & 1.0 & 1.0 & 1.0 \\
\hline MDL for vegetable $(\mathrm{mg} / \mathrm{kg})$ & 0.01 & 0.02 & 0.01 & 0.02 & 0.02 & 0.05 \\
\hline
\end{tabular}

Validation of the analytical data

The validation of the analytical data using t-test for validation of the analytical procedure, a recovery study was carried out by using standard reference materials (spiking for water and vegetable samples and BM 162 for soil sample) obtained from Ezana Mining PLC, Mekelle, Tigray, Ethiopia. The means of the results were compared with the corresponding certified values and then calculating the percentage recoveries.

\section{Transfer factor (TF)}

Transfer factor is the relative tendency of a metal to be accumulated by a particular species of plant. It expresses by the bioavailability of a metal at a particular position on a species of plant. It is the ratio of the concentration of heavy metal in a plant to the concentration of heavy metal in soil, which is described as [11].

$$
T F=\frac{\text { concentration of metal in edible part of vegetable }}{\text { concentration of metal in soil }}
$$

Daily intake of metal (DIM)

The daily intake of metals (DIM) was calculated to averagely estimated the daily metal loading into the body system of a specified body weight of a consumer which informs the relative phytoavailability of metal $[11,12]$ The daily intake metals (DIM) was determined as follow:

$$
D I M=\frac{\text { Cmetal } \times \mathrm{C} \text { factor } \times \mathrm{D} \text { food intake }}{\mathrm{BW}}
$$

where: $\mathrm{C}$ metal $=$ heavy metal concentrations in plants $(\mathrm{mg} / \mathrm{kg}), \mathrm{C}$ factor $=$ conversion factor (i.e.to convert fresh vegetable weight to dry weight), $\mathrm{D}$ food intake $=$ daily intake of vegetables, $\mathrm{BW}=$ average body weight $(65 \mathrm{~kg})$ and conversion factor of 0.085 is to convert fresh vegetable weight to dry weight.

\section{Reference oral dose (RfDo)}

Reference oral dose (RfDo) is an estimated exposure of metal to the human body per day that has no hazardous effect during life time [13]. The value of oral reference doses (RfDo) for the heavy metals obtained at the present study is summarized in Table 2.

Table 2. Oral reference doses (RfDO) $\mathrm{mg} / \mathrm{kg} /$ day for heavy metals.

\begin{tabular}{|l|l|l|}
\hline Heavy Metal & RfDo (mg/kg/day) & References \\
\hline $\mathrm{Fe}$ & 0.7 & {$[14]$} \\
\hline $\mathrm{Zn}$ & 0.3 & {$[5,14,15,16,17]$} \\
\hline $\mathrm{Cu}$ & 0.04 & {$[5,14,16,17,18]$} \\
\hline $\mathrm{Pb}$ & 0.004 & {$[5,13,14]$} \\
\hline $\mathrm{Cr}$ & 1.5 & {$[13,14]$} \\
\hline $\mathrm{Cd}$ & 0.001 & {$[5,13,14,17,18]$} \\
\hline
\end{tabular}

Bull. Chem. Soc. Ethiop. 2018, 32(1) 


\section{Health risk index (HRI)}

The health risk index (HRI) was determined as described as follows [19]: HRI = DIM/RfDo. Human are considered to be safe if HRI $<1[20]$.

\section{Statistical analysis}

All the data were analyzed statistically using SAS 9.1 and Microsoft office 2010 and variation of each parameter between sites was analyzed using one way ANOVA at $95 \%$ confidence level. When tests indicated significant differences between the sampling sites, the mean values were given a different letter $(\mathrm{a}, \mathrm{b}$ or $\mathrm{c})$.

\section{RESULTS AND DISCUSSION}

\section{Method validation}

In the present study, the method validations were made by the spiking experiment for water and spinach samples and reference standard material (BM 162) for soil sample. The obtained percent recovery varied from $95.0 \%$ to $101 \%, 96.3 \%$ to $102 \%$, and $102 \%$ to $117 \%$ for water, soil and spinach, respectively, which were in the acceptable range (Table 3 ).

Table 3. Validation of the analytical method using water, soil and vegetable reference materials (Mean $\pm \mathrm{SD}$ in $\mathrm{mg} / \mathrm{L})$.

\begin{tabular}{|c|c|c|c|c|c|c|c|c|c|}
\hline \multirow[t]{3}{*}{ Metals } & \multicolumn{3}{|c|}{$\begin{array}{l}\text { Water reference material } \\
\text { (spiking) }(\mathrm{N}=6)\end{array}$} & \multicolumn{3}{|c|}{$\begin{array}{l}\text { Soil reference material (BM 162) } \\
\qquad(\mathrm{N}=10)\end{array}$} & \multicolumn{3}{|c|}{$\begin{array}{l}\text { Plant reference material (Spiking) } \\
\qquad(\mathrm{N}=6)\end{array}$} \\
\hline & $\begin{array}{c}\text { Measured } \\
\text { Value }\end{array}$ & Reference & $\begin{array}{c}\% \\
\text { Recovery }\end{array}$ & $\begin{array}{c}\text { Measured } \\
\text { Value }\end{array}$ & Reference & $\begin{array}{c}\% \\
\text { Recovery }\end{array}$ & $\begin{array}{c}\text { Measured } \\
\text { Value }\end{array}$ & Reference & $\begin{array}{c}\% \\
\text { Recovery }\end{array}$ \\
\hline & Mean \pm SD & Value \pm SD & & Mean \pm SD & Value \pm SD & & Mean \pm SD & Value \pm SD & \\
\hline $\mathrm{Fe}$ & $0.98 \pm 0.01$ & $1.00 \pm 0.01$ & 95.0 & $313 \pm 59$ & $309 \pm 65$ & 101 & $144 \pm 29$ & $114 \pm 17$ & 117 \\
\hline $\mathrm{Zn}$ & $0.98 \pm 0.01$ & $1.00 \pm 0.01$ & 98.0 & $98.4 \pm 9.0$ & $100 \pm 8$ & 98.4 & $10.9 \pm 2.21$ & $10.5 \pm 2.1$ & 104 \\
\hline $\mathrm{Cu}$ & $0.99 \pm 0.02$ & $1.00 \pm 0.01$ & 99.0 & $53.9 \pm 3.9$ & $56 \pm 6.4$ & 96.3 & $2.26 \pm 0.45$ & $2.20 \pm 0.71$ & 103 \\
\hline $\mathrm{Pb}$ & $1.01 \pm 0.02$ & $1.00 \pm 0.01$ & 101 & $8.8 \pm 1.0$ & $9 \pm 0.89$ & 97.8 & $7.72 \pm 1.56$ & $6.77 \pm 0.87$ & 114 \\
\hline $\mathrm{Cr}$ & $0.96 \pm 0.02$ & $1.00 \pm 0.01$ & 96.0 & $106 \pm 9$ & $104 \pm 12$ & 102 & $0.63 \pm 0.13$ & $0.62 \pm 0.15$ & 102 \\
\hline $\mathrm{Cd}$ & $0.98 \pm 0.04$ & $1.00 \pm 0.01$ & 98.0 & $0.96 \pm 0.12$ & $0.98 \pm 0.10$ & 98.0 & $0.35 \pm 0.07$ & $0.32 \pm 0.03$ & 111 \\
\hline
\end{tabular}

Heavy metal concentrations in water, soil and spinach samples of Elalla River

Currently, there is a gradual increase in consumption of vegetables particularly among urban communities, due to increased awareness on food value of the vegetables, as a result of the exposure to proper education [21]. But, leafy vegetables have the tendency to accumulate heavy metals and this accumulation has health problems [22]. The concentration of the six heavy metals from water, soil and spinach vegetable samples of Elalla River was summarized in Table 4. The concentrations of $\mathrm{Fe}, \mathrm{Zn}, \mathrm{Cu}, \mathrm{Pb}, \mathrm{Cr}$ and $\mathrm{Cd}(\mathrm{mg} / \mathrm{L})$ recorded in water samples of Elalla River are ranged from $3.07 \pm 0.11$ to $6.33 \pm 0.28,0.27 \pm 0.02$ to $0.97 \pm 0.09,0.05 \pm 0.003$ to $0.07 \pm 0.005,0.02 \pm 0.001$ to $0.04 \pm 0.002,0.18 \pm 0.006$ to $0.60 \pm 0.007$ and $0.021 \pm 0.001$ to $0.023 \pm 0.001$, respectively. As Table 4 indicates the concentration of heavy metals in water was the highest for $\mathrm{Fe}$ followed by $\mathrm{Zn}, \mathrm{Cr}, \mathrm{Cu}, \mathrm{Pb}$ and $\mathrm{Cd}$. The concentrations of $\mathrm{Fe}, \mathrm{Cr}$ and $\mathrm{Cd}$ in irrigation water measured during this study were above the FAO permissible limits of heavy metals allowed in the irrigation water [23], whereas $\mathrm{Zn}, \mathrm{Cu}$ and $\mathrm{Pb}$ are below the FAO permissible limits for irrigation water [23]. Lower results for $\mathrm{Zn}, \mathrm{Cu}$ and $\mathrm{Pb}$ were also observed in irrigation waters [24]. The reason to increase concentration of $\mathrm{Fe}, \mathrm{Cr}$ and $\mathrm{Cd}$ above measurable limits might be due to some metal works takes from the small scale industries, 
weathering of sulfide ores and igneous, sedimentary and metamorphic rocks and by corrosion of iron and steel, discarded chromium batteries and leachates from the city and through washing of different vehicles at the river, release of cadmium batteries from the cars, agricultural and surface run-off, and the discharges from the town [25-27]. Except S3 for Fe and S3 and S4 for $\mathrm{Zn}$, the $95 \%$ confidence level statistical analysis showed no significance difference among the sampling sites of all studied metals (Table 4).

The concentration of heavy metals in irrigated soil was highest for $\mathrm{Fe}$, followed by $\mathrm{Zn}, \mathrm{Cr}$, $\mathrm{Cu}, \mathrm{Cd}$ and $\mathrm{Pb}$. The highest concentrations of $\mathrm{Cu}$ at $\mathrm{S} 1 ; \mathrm{Zn}, \mathrm{Pb}$ and $\mathrm{Cr}$ at $\mathrm{S} 2 ; \mathrm{Fe}$ and $\mathrm{Cd}$ at $\mathrm{S} 3$ in the soil sample could be due to chemical fertilizers and pesticides used in agricultural land of the catchments, emission of $\mathrm{Pb}$ from vehicles, discharge of motor oil, grease, fuel burning and a battery from the road side and near the bridge [28]. The concentrations of $\mathrm{Fe}, \mathrm{Cu}, \mathrm{Pb}$ and $\mathrm{Cr}$ under this study were below the permissible limits of concentrations for soil whereas $\mathrm{Zn}$ and $\mathrm{Cd}$ are above the maximum permissible level [25]. For $\mathrm{Zn}, \mathrm{Cu}, \mathrm{Pb}, \mathrm{Cr}$ and $\mathrm{Cd}$ the statistical analysis at the $95 \%$ confidence level indicated that there is no statistically significance difference (at $\mathrm{p}<$ 0.05 ) in all sampling sites (Table 4). But for Fe the analysis showed that S1 and S4 are significantly different from S2 and S3. This might be due to higher anthropogenic activities at around S2 and S3. Generally, soil of the agricultural fields from where spinach vegetable sample collected is highly contaminated with $\mathrm{Zn}, \mathrm{Fe}$ and $\mathrm{Cd}$ metal ions which can pose serious health hazards to human health on consumption of vegetables.

Table 4. Concentration of heavy metals in water, soil and spinach vegetable samples of Elalla River.

\begin{tabular}{|c|c|c|c|c|c|c|c|}
\hline \multirow[t]{2}{*}{ Sample } & \multirow[t]{2}{*}{ Site } & \multicolumn{6}{|c|}{ Mean of heavy metal concentration, $\mathbf{N}=\mathbf{9}$} \\
\hline & & $\mathrm{Fe}$ & $\mathrm{Zn}$ & $\mathrm{Cu}$ & $\mathrm{Pb}$ & $\mathrm{Cr}$ & $\mathrm{Cd}$ \\
\hline \multirow{6}{*}{ 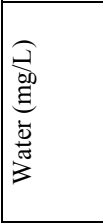 } & $\mathrm{S} 1$ & $3.70 \pm 0.064^{\mathrm{b}}$ & $0.53 \pm 0.016^{\mathrm{ab}}$ & $0.07 \pm 0.005^{\mathrm{a}}$ & $0.02 \pm 0.001^{\mathrm{a}}$ & $0.18 \pm 0.006^{\mathrm{a}}$ & $0.021 \pm 0.001^{\mathrm{a}}$ \\
\hline & $\mathrm{S} 2$ & $3.84 \pm 0.076^{b}$ & $0.56 \pm 0.026^{\mathrm{ab}}$ & $0.05 \pm 0.003^{\mathrm{ba}}$ & $0.04 \pm 0.002^{\mathrm{a}}$ & $0.60 \pm 0.007^{\mathrm{a}}$ & $0.021 \pm 0.001^{\mathrm{a}}$ \\
\hline & S3 & $6.33 \pm 0.28^{\mathrm{a}}$ & $0.97 \pm 0.087^{\mathrm{a}}$ & $0.07 \pm 0.001^{\mathrm{a}}$ & $0.03 \pm 0.002^{\mathrm{a}}$ & $0.29 \pm 0.002^{\mathrm{a}}$ & $0.023 \pm 0.001^{\mathrm{a}}$ \\
\hline & $\mathrm{S} 4$ & $3.07 \pm 0.11^{\mathrm{b}}$ & $0.27 \pm 0.016^{\mathrm{b}}$ & $0.05 \pm 0.003^{\mathrm{ba}}$ & $0.03 \pm 0.001^{\mathrm{a}}$ & $0.18 \pm 0.008^{\mathrm{a}}$ & $0.021 \pm 0.001^{\mathrm{a}}$ \\
\hline & \begin{tabular}{|l|} 
Ayers and \\
Westcot [23]
\end{tabular} & 5.0 & 2.0 & 0.20 & 5.0 & 0.10 & 0.01 \\
\hline & S1 & $604 \pm 12^{\mathrm{b}}$ & $392 \pm 8^{\mathrm{ab}}$ & $40.9 \pm 1.8^{\mathrm{a}}$ & $1.57 \pm 0.02^{\mathrm{a}}$ & $42.8 \pm 1.4^{\mathrm{a}}$ & $16.1 \pm 1.4^{\mathrm{a}}$ \\
\hline \multirow{5}{*}{ 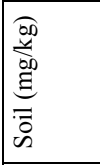 } & S2 & $816 \pm 15^{\mathrm{a}}$ & $518 \pm 3^{\mathrm{a}}$ & $40.6 \pm 1.2^{\mathrm{a}}$ & $2.19 \pm 0.1^{\mathrm{a}}$ & $53.8 \pm 3.0^{\mathrm{a}}$ & $16.1 \pm 1.3^{\mathrm{a}}$ \\
\hline & \begin{tabular}{|l|} 
S3 \\
\end{tabular} & $871 \pm 16^{\mathrm{a}}$ & $324 \pm 8^{b}$ & $39.5 \pm 2.5^{\mathrm{a}}$ & $1.95 \pm 0.07^{\mathrm{a}}$ & $48.8 \pm 1.79^{\mathrm{a}}$ & $16.8 \pm 0.6^{\mathrm{a}}$ \\
\hline & \begin{tabular}{|l|}
$\mathrm{S} 4$ \\
\end{tabular} & $614 \pm 12^{b}$ & $316 \pm 6^{b}$ & $39.1 \pm 0.5^{\mathrm{a}}$ & $0.61 \pm 0.05^{\mathrm{b}}$ & $43.4 \pm 2.55^{\mathrm{a}}$ & $16.0 \pm 1.4^{\mathrm{a}}$ \\
\hline & Ewers [29] & 5000 & 300 & 100 & 100 & 100 & 3.00 \\
\hline & S1 & $537 \pm 14^{\mathrm{a}}$ & $208 \pm 15^{\mathrm{ab}}$ & $13.4 \pm 0.8^{\mathrm{c}}$ & $2.56 \pm 0.09^{\mathrm{a}}$ & $8.42 \pm 0.55^{\mathrm{a}}$ & $1.70 \pm 0.02^{\mathrm{a}}$ \\
\hline \multirow{5}{*}{ 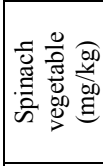 } & S2 & $552 \pm 2^{\mathrm{a}}$ & $220 \pm 8^{\mathrm{a}}$ & $23.9 \pm 0.7^{\mathrm{a}}$ & $3.64 \pm 0.01^{\mathrm{a}}$ & $12.4 \pm 0.7^{\mathrm{a}}$ & $1.91 \pm 0.07^{\mathrm{a}}$ \\
\hline & S3 & $612 \pm 18^{a}$ & $192 \pm 14^{\mathrm{ab}}$ & $16.7 \pm 0.3^{b}$ & $3.97 \pm 0.08^{\mathrm{a}}$ & $13.5 \pm 0.4^{\mathrm{a}}$ & $1.80 \pm 0.04^{\mathrm{a}}$ \\
\hline & $\mathrm{S} 4$ & $483 \pm 16^{\mathrm{a}}$ & $110 \pm 10^{b}$ & $14.2 \pm 0.1^{\mathrm{cb}}$ & $3.67 \pm 0.03^{\mathrm{a}}$ & $11.7 \pm 0.8^{\mathrm{a}}$ & $1.62 \pm 0.06^{\mathrm{a}}$ \\
\hline & \begin{tabular}{|l|} 
Weigert [30] \\
\end{tabular} & 425 & 100 & 70.0 & $0.30 *$ & 2.30 & $0.20^{*}$ \\
\hline & Weigert [30] & 425 & 100 & 70.0 & $0.30 *$ & 2.30 & $0.20 *$ \\
\hline \multicolumn{8}{|c|}{${ }^{*}$ Source: FAO/WHO [31] } \\
\hline
\end{tabular}

The mean concentrations of heavy metals $(\mathrm{mg} / \mathrm{kg})$ in the spinach grown around Elalla River showed elevated level of concentrations in $\mathrm{Fe}, \mathrm{Zn}, \mathrm{Pb}$ and $\mathrm{Cd}$ which are higher than maximum permissible limit set for vegetables by Weigert and FAO/WHO, respectively [30,31]. The overall results of the studied heavy metals $(\mathrm{mg} / \mathrm{kg})$ ranged $467-630,101-228,12.6-24.6$, 2.47 - 3.98, 7.32 - 13.8 and 1.56 - 1.98 for $\mathrm{Fe}, \mathrm{Zn}, \mathrm{Cu}, \mathrm{Pb}, \mathrm{Cr}$ and $\mathrm{Cd}$, respectively. The one way ANNOVA at $95 \%$ confidence level for $\mathrm{Fe}, \mathrm{Pb}, \mathrm{Cr}$ and $\mathrm{Cd}$ showed no significance differences among the sampling sites but $\mathrm{Zn}$ and $\mathrm{Cu}$ are significantly differ (Table 4). As the result indicated in Table 4, high Fe content in plant sample recorded at S3 could be due to discharge of Fe effluents from metal works which enter the farmland and then the plant accumulates from the soil. The high level of $\mathrm{Zn}, \mathrm{Cu}$ and $\mathrm{Cd}$ recorded in $\mathrm{S} 2$ could also be due to the discharge from the 
road sides, the use of wastewater for irrigation from the bridge in which different vehicles were washed, by the improper disposal of municipal as well as domestic waste and sewage from different garages and construction works of the city in to the irrigated soil and to the river. Generally, the trend for heavy metal content in spinach leafy vegetable was observed as follows: $\mathrm{Fe}>\mathrm{Zn}>\mathrm{Cu}>\mathrm{Cr}>\mathrm{Pb}>\mathrm{Cd}$. The $\mathrm{Pb}$ and $\mathrm{Cd}$ are toxic elements that can be harmful to plants, and the plants usually show ability to accumulate large amounts of $\mathrm{Pb}$ and $\mathrm{Cd}$ without visible changes in their appearance or yield. Thus, spinach is green and leafy vegetables possessing large surface areas, relatively high growth rates and rather elevated heavy metal absorption rates [32].

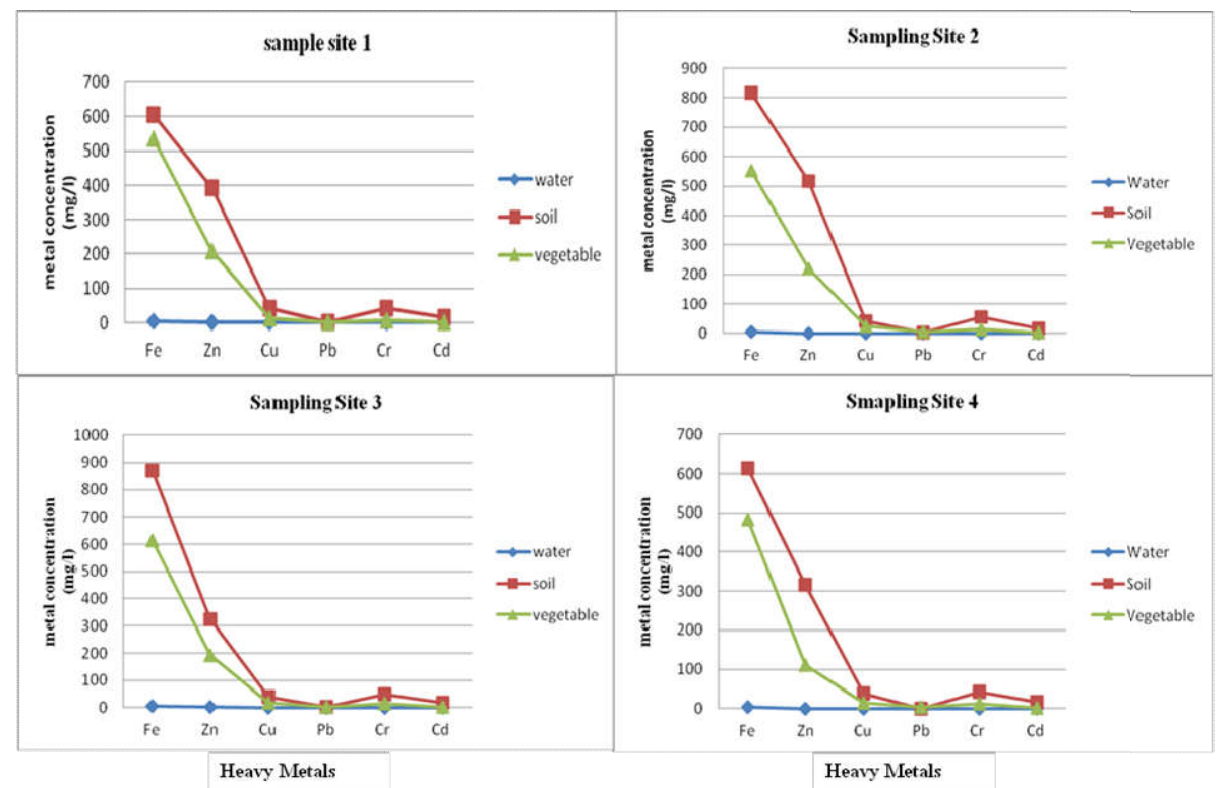

Figure 2. Comparison of the concentration of heavy metals in water, vegetable and soil in four sampling sites of Elalla River.

Comparison of concentration of selected heavy metals among water, vegetable and soil samples of Elalla River

The trend of the concentration of all selected heavy metals were in the order of soil $>$ vegetable $>$ water (Figure 2). The higher concentration of heavy metals recorded in soils for all studied metals could be due to the contamination by the accumulation of heavy metals through emissions from the rapidly expanding small scale industrial areas, disposal of high metal wastes, application of fertilizers, animal manures, sewage sludge, pesticides and the wastewater used for irrigation. But, the concentrations of metals in vegetables were generally lower than that of the corresponding soils attributed to the leaf, which seems to act as a barrier to the translocation of metals based its accumulation capacity from the soil to plant [3].

\section{Health risk assessment of Elalla River}

Bioavailability of heavy metals in soil is assumed to be available to plants. As a result, heavy metals can transfer to plant when they are in a mobile form. To estimate the heavy metals transferred to plants, the transfer factor, a function of both soil and plant properties, is used due 
to its representative bioavailability of heavy metals to plants. Values of TF decreases with increasing respective metal concentration in soils, whereas increases with increasing the concentration of metal in edible vegetable [18]. Scholars showed the TF does not represent the risk associated with the metals rather it helps to know the source of metal contaminants based on their quantitative values [15]. The transfer factors from the soil to the spinach leafy vegetable and daily intake of heavy metals $(\mathrm{mg} / \mathrm{kg})$ are summarized in Table 5 . The heavy metal transfer factor in the spinach vegetables from the study area grown at the Elalla river of four sites were ranged from 0.677 to $0.874,0.348$ to $0.591,0.327$ to $0.589,1.63$ to $6.00,0.197$ to $0.275,0.101$ to 0.269 for $\mathrm{Fe}, \mathrm{Zn}, \mathrm{Cu}, \mathrm{Pb}, \mathrm{Cr}$ and $\mathrm{Cd}$, respectively. Trend of metal TF from soil to spinach vegetables grown at Elalla river side was in the order of $\mathrm{Pb}>\mathrm{Fe}>\mathrm{Zn}>\mathrm{Cu}>\mathrm{Cr}>\mathrm{Cd}$. The average $\mathrm{TF}$ values for $\mathrm{Pb}$ and $\mathrm{Fe}$ are greater than 0.5 which indicates the greater metal contamination of vegetables by anthropogenic activities like different metal works that takes place at the city and washing of different automobiles at the river [33]. The spinach vegetable from this study is good bio accumulators of lead. Hence, the vegetable is potential health hazards as the build-up of lead in the human system has deleterious consequences at the long run [34].

Daily intake of heavy metals (DIM)

Most people consume vegetables about $117 \mathrm{~g} /$ day which is called provisional tolerable daily intake (PTDI) vegetable that helps for estimating the consumer based health risk assessment [35]. The degree of toxicity of heavy metals to human being depends upon their daily intake. The DIM was found to be the highest for Fe followed by $\mathrm{Zn}, \mathrm{Cu}, \mathrm{Cr}, \mathrm{Pb}$ and $\mathrm{Cd}$, respectively (Table 5). The findings of this study regarding DIM suggest that the consumption of spinach vegetable grown using Ellala River have highest DIM for the heavy metals like Fe (0.083) and $\mathrm{Zn}(0.028)$ than the other studied heavy metals but is nearly free of risks, as the dietary intake limits of $\mathrm{Fe}$, and $\mathrm{Zn}$ in adults can range from 10.0 to 50.0 and 5.0 to $22.0 \mathrm{mg}$, respectively [36]. The higher DIM values of $\mathrm{Fe}$ and $\mathrm{Zn}$ than the remaining heavy metals might be due to highest values of concentration of the two metals in the spinach leafy vegetable. Similar results were also observed in Kidu et al. [37].

Table 5. Soil to the spinach vegetable transfer factors (TF), daily intake of heavy metals (DIM) $(\mathrm{mg} / \mathrm{kg}$ ) and health risk index (HRI) of heavy metals.

\begin{tabular}{|c|c|c|c|c|c|c|c|}
\hline \multirow[b]{2}{*}{ Measurements } & \multirow[b]{2}{*}{ Site } & \multicolumn{6}{|c|}{ Mean of heavy metals } \\
\hline & & $\mathrm{Fe}$ & $\mathrm{Zn}$ & $\mathrm{Cu}$ & $\mathrm{Pb}$ & $\mathrm{Cr}$ & $\mathrm{Cd}$ \\
\hline \multirow{5}{*}{ 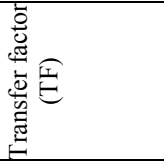 } & $\mathrm{S} 1$ & 0.874 & 0.530 & 0.327 & 1.631 & 0.197 & 0.269 \\
\hline & $\mathrm{S} 2$ & 0.677 & 0.424 & 0.589 & 1.660 & 0.230 & 0.118 \\
\hline & S3 & 0.703 & 0.591 & 0.423 & 2.038 & 0.275 & 0.107 \\
\hline & S4 & 0.800 & 0.348 & 0.363 & 5.998 & 0.269 & 0.101 \\
\hline & Average TF & 0.764 & 0.473 & 0.423 & 2.832 & 0.243 & 0.149 \\
\hline \multirow{5}{*}{ 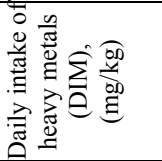 } & $\mathrm{S} 1$ & 0.082 & 0.032 & 0.0021 & 0.00039 & 0.0013 & 0.00026 \\
\hline & $\mathrm{S} 2$ & 0.084 & 0.034 & 0.0037 & 0.00056 & 0.0019 & 0.00029 \\
\hline & S3 & 0.093 & 0.029 & 0.0026 & 0.00061 & 0.0021 & 0.00027 \\
\hline & S4 & 0.074 & 0.017 & 0.0022 & 0.00056 & 0.0018 & 0.00025 \\
\hline & Average DIM & 0.083 & 0.028 & 0.003 & 0.0005 & 0.002 & 0.0003 \\
\hline \multirow{5}{*}{ 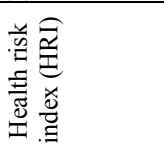 } & $\mathrm{S} 1$ & 0.117 & 0.107 & 0.053 & 0.098 & 0.0009 & 0.260 \\
\hline & $\mathrm{S} 2$ & 0.120 & 0.113 & 0.093 & 0.140 & 0.0013 & 0.290 \\
\hline & S3 & 0.133 & 0.097 & 0.065 & 0.153 & 0.0014 & 0.270 \\
\hline & $\mathrm{S} 4$ & 0.106 & 0.057 & 0.055 & 0.14 & 0.0012 & 0.250 \\
\hline & Average HRI & 0.119 & 0.094 & 0.067 & 0.133 & 0.0012 & 0.268 \\
\hline
\end{tabular}




\section{Health risk index (HRI)}

The HRI represents the harmful effect of heavy metals to people in which consume vegetables contaminated with them. When the value of HRI is $<1$, people will be safe to eat those kinds of vegetables $[13,15]$. Although the HRI values of all studied heavy metals (Table 5) were less than one, the values for $\mathrm{Cd}$ and $\mathrm{Pb}$ were higher than the other heavy metals which possibly considered as the most significant heavy metals affecting leafy vegetables and really alarming for the long term use of spinach in the studied area. The spinach vegetable grown at river side of Elalla was found to be nearly free of risk from the other studied heavy metals but long term use of heavy metal contamination may lead health risk to consumers. Similar result was also observed for Cd in Kidu et al. [37].

\section{CONCLUSION}

The present finding showed that water, soil and leafy vegetable quality from river water irrigated sites of Elalla River and associated risk assessment for consumer exposure to heavy metals. Almost all of assessed heavy metals except $\mathrm{Zn}$ and $\mathrm{Cu}$ in water; $\mathrm{Fe}, \mathrm{Cu}, \mathrm{Pb}$ and $\mathrm{Cr}$ in soil; $\mathrm{Cu}$ in spinach vegetable of the Elalla River water was found to be above the recommended limit for irrigation water, irrigation soil and contents of metals at plants used as food. From the result it was noticed that the toxicity levels of heavy metals were found to be several fold higher in all the collected samples from river water irrigated sites of Elalla River. The finding of this study regarding DIM and HRI showed that the consumption of vegetables grown in Elalla River water irrigated soils was nearly free of risks at all sites for all assessed heavy metals. Even though the value of HRI was below one, the long term use caused heavy metal contamination leading to health risk to consumers which is needed urgent attention to advise and implement appropriate means of maintaining and regulating domestic effluent and providing appropriate advice and support for the safe and productive use of polluted water for irrigation.

\section{ACKNOWLEDGMENTS}

This study was financially supported by Mekelle University, Ethiopia. The authors thank Mr. Alem Halefom, Department of Chemistry, Mekelle University for his kind help in sample preparation and Ezana Analytical Laboratory, Ezana Mining Development PLC, Mekelle, Tigray, Ethiopia, for allowing to use the FAAS for the heavy metal analysis.

\section{REFERENCES}

1. Okweye, P.S. Seasonal variation in physico-chemical parameters and heavy metals assessment in surface water of North Alabama. Res. J. Chem. Environ. 2013, 17, 68-115.

2. Modaihsh, A.S.; AL-Swailem, M.S.; Mahjoub, M.O. Heavy metals content of commercial inorganic fertilizers used in the Kingdom of Saudi Arabia. Agric. Marine Sci. 2004, 9, 21 25 .

3. Wuana, R.A.; Okieimen, F.E. Heavy metals in contaminated soils: a review of sources, chemistry, risks and best available strategies for remediation. ISRN Ecol. 2011, 2011, Article ID 402647, DOI: 10.5402/2011/402647.

4. Akan, J.C.; Abdulrahman, F.I.A.; Ogugbuaja, V.O.; Ayodele, J.T. Heavy metals and anion levels in some samples of vegetable grown within the vicinity of Challawa industrial area, Kano State, Nigeria. Am. J. Appl. Sci. 2009, 6, 534-542.

5. Jolly, Y.N.; Akter, S.; Kabir, J.; Islam, A. Health risk assessment of heavy metals via dietary intake of vegetables collected from an area selected for introducing a nuclear power plant. Res. J. Phys. Appl. Sci. 2013, 2, 43-51. 
6. Forstner, U.; Wittmann, G.T. Metal Pollution in the Aquatic Environment, Springer Verlag: Berlin; 1979; p 99.

7. Mebrahtu, G.; Zerabruk, S. Concentration and health implication of heavy metals in drinking water from urban areas of Tigray Region, Northern Ethiopia. Momona Ethiop. J. Sci. 2011, 3, 105-121.

8. Gangwar, R.K.; Khare, P.; Singh, J.; Singh, A.P. Assessment of physico-chemical properties of water: River Ramganga at Bareilly, UP. J. Chem. Pharm. Res. 2012, 4, 4231-4234.

9. Aderinola, O.J.; Kusemiju, V. Heavy metals concentration in garden lettuce (Lactuca sativa L.) grown along badagry expressway, Lagos, Nigeria. Transnat. J. Sci. Tech. 2012, 2, $115-$ 130.

10. Inoti, K.J.; Fanuel, K.; George, O.; Paul, O. Assessment of heavy metal concentrations in urban grown vegetables in Thika Town, Kenya. Afr. J. Food Sci. 2012, 6, 41-46.

11. Ali, M.F. and Shakrani, S.A. Risk associated with secondary treated wastewater on mustard greens growth under soil and soilless culture. IJCEE 2012, 12, 18-27.

12. Mahmood, A.; Malik, R.N. Human health risk assessment of heavy metals via consumption of contaminated vegetables collected from different irrigation sources in Lahore, Pakistan. Arab. J. Chem. 2014, 7, 91-99.

13. Yang, T.; Liu, J. Health risk assessment and spatial distribution characteristic on heavy metals pollution of Haihe River Basin. J. Environ. Anal. Toxicol. 2012, 2:152, DOI: 10.4172/2161-0525.1000152.

14. Chauhan, G.; Chauhan, U.K. Risk assessment of heavy metal toxicity through contaminated vegetables from waste water irrigated area of Rewa (MP), India. Int. J. Adv. Technol. Eng. Sci. 2014, 2, 444-460.

15. Akoto, O.; Bismark Eshun, F.; Darko, G.; Adei, E. Concentrations and health risk assessments of heavy metals in fish from the Fosu Lagoon. Int. J. Environ. Res. 2014, 8, 403-410.

16. Ogunkunle, C.O.; Fatoba, P.O.; Ogunkunle, M.O.; Oyedeji, A.A. Potential health risk assessment for soil heavy metal contamination of Sagamu, South-west Nigeria due to cement production. IJAST 2013, 3, 89-96.

17. Kachenko, A.G.; Singh, B. Heavy metals contamination in vegetables grown in urban and metal smelter contaminated sites in Australia. Water Air Soil Pollut. 2006, 169, 101-123.

18. Aremu, M.O.; Gav, B.L.; Opaluwa, O.D.; Atolaiye, B.O.; Madu, P.C.; Sangari, D.U. Assessment of physicochemical contaminants in waters and fishes from selected rivers in Nasarawa State, Nigeria. Res. J. Chem. Sci. 2011, 1, 6-17.

19. IRIS. Integrated Risk Information System - China via consumption of vegetables and fish. Science Database, US Envrionmental Protection Agency; USA; 2003.

20. Silambarasan, K.; Senthilkumaar, P.; Velmurugan, K. Studies on the distribution of heavy metal concentrations in River Adyar, Chennai Tamil Nadu. Euro. J. Exp. Biol. 2012, 2, 2192-2198.

21. Itanna, F. Metals in leafy vegetables grown in Addis Ababa and toxicological implications. Ethiop. J. Health Dev. 2002, 16, 295-302.

22. Gebrekidan, A., Weldegebrial, Y.; Hadera, A.; Van Der Bruggen, B. Toxicological assessment of heavy metals accumulated in vegetables and fruits grown in Ginfel River near Sheba Tannery, Tigray, Northern Ethiopia. Ecotoxicol. Environ. Saf. 2013, 95, 171-178.

23. Ayers, R.S.; Westcott, D.W. Water quality for agriculture. FAO Irrigation and Drainage Paper, 1985, 29, 1-120.

24. Kitata, R.B., Chandravanshi, B.S. Concentration levels of major and trace metals in onion (Allium cepa L.) and irrigation water around Meki town and Lake Ziway. Bull. Chem. Soc. Ethiop. 2012, 26, 27-42. 
25. Hong, A.H.; Law, P.L.; Selaman, O.S. Physicochemical quality assessment of pollutants in river Benue water in Jimeta/Yola metropolitan, Adamawa State, North Eastern Nigeria. AJEP 2014, 3, 90-95.

26. Ghorade, I.; Lamture, S.; Patil, S. Assessment of heavy metal content in Godavari River water. IJRANSS 2014, 2, 23-26.

27. Ewers, U. Standards, guidelines and legislative regulations concerning metals and their compounds in Metal and Their Compounds in the Environment: Occurrence, Analysis and Biological Relevance, Maria, E. (Ed.), VHC: Wenheim; 1991; p 458.

28. Doamekpor, L.K.; Darko, R.; Klake, R.K; Samlafo, V.B.; Bobobee, L.H.; Akpabli, C.K.; Nartey, V.K. Assessment of the contribution of road runoffs to surface water pollution in the New Juaben Municipality, Ghana. J. Geosci. Environ. Prot. 2016, 4, 173-190.

29. Ewers, U. Standards, guidelines and legislative regulations concerning metals and their compounds in Metals and Their Compounds in the Environment: Occurrence, Analysis and Biological Relevance, Merian, E. (Ed.), VCH: Weinheim; 1991; 458.

30. Weigert, P. Metal load of food vegetables origin including mushrooms. In: Maria, E (Ed.), Metal and their compounds in the environment: Occurrence, Analysis and Biological Relevance.VHC, Wenheim; 1991, p 458.

31. Joint FAO/WHO food standards programme codex committee on contaminants in foods. Fifth session; 2011, p 64.

32. Naz, A.; Khan, S.; Muhammad S.; Khalid S.; Alam S.; Siddique S.; Ahmed T.; Scholz M. Toxicity and bioaccumulation of heavy metals in spinach (Spinacia oleracea) grown in a controlled environment. Int. J. Environ. Res. Public Health 2015, 12, 7400-7416.

33. Mollazadeh, N. Metals health risk assessment via consumption of vegetables. Int. J. Agric. Crop Sci. 2014, 7, 433-436.

34. Dingkwoet, D.J.; Danladi, S.M.; Gabriel, M.S. Comparative study of some heavy and trace metals in selected vegetables from four Local Government Areas of Plateau State, Nigeria. IOSR-JESTFT 2013, 6, 86-93.

35. Khan, S.; Farooq, R.; Shahbaz, S.; Khan, M.A.; Sadique, M. Health risk assessment of heavy metals for population via consumption of vegetables. World Appl. Sci. J. 2009, 6, 1602-1606.

36. World Health Organization (WHO). Health Criteria Other Supporting Information in Guidelines for Drinking Water Quality, Vol. 2, 2nd ed., WHO: Geneva; 1996; pp. 31-338.

37. Mezgebe, K.; Gebrekidan, A.; Hadera, A.; Weldegebriel, Y. Assessment of the distribution and their health risk of trace metals in Tsaeda Agam River, Mekelle City, Tigray, Northern Ethiopia. J. Environ. Anal. Toxicol. 2015, 5:283, DOI: 10.4172/2161-0525.1000283. 